\title{
What's That Smell? Why the Tenth Circuit Should Discard Its Distinction Between the Odors of Burnt and Raw Marijuana*
}

\section{INTRODUCTION}

In a unique line of cases, the United States Court of Appeals for the Tenth Circuit became the first and only federal circuit to adopt a standard that alters the permissible scope of a warrantless search of an automobile by distinguishing between the odors of burnt and raw marijuana. ${ }^{1}$ Under this principle, a law enforcement officer's recognition of the smell of raw marijuana emanating from inside a vehicle automatically establishes the requisite probable cause to search the entire automobile, including the trunk or anywhere else narcotics might be concealed. ${ }^{2}$ However, should an officer recognize the smell of burnt marijuana instead, probable cause to search the automobile extends only to the passenger compartment unless other corroborating evidence provides a reasonable basis to search elsewhere. ${ }^{3}$

Although development of this rule began with United States $v$. Nielsen, ${ }^{4}$ the rule's framework and the legal arguments asserted in support of Nielsen have evolved over time. But the black letter rule outlined in Nielsen and its progeny is not the product of legal reasoning based on Fourth Amendment jurisprudence. Rather, a closer reading of the Nielsen decision indicates that the distinction is based on the Tenth Circuit's determination that the law-enforcement officer manufactured testimony to legitimize an otherwise unconstitutional search. Subsequent

Joshua Bender. J.D. conferred Dec. 2009, The University of Kansas.

1. See Kevin Corr, A Law Enforcement Primer on Vehicle Searches, 30 LoY. U. CHI. L.J. 1, 17 (1999) ("[O]ne court has held that such an odor [burnt marijuana] is not enough, when followed by a fruitless search of the passenger compartment, to justify a search of the trunk as the officer found nothing to corroborate the odor.").

2. See United States v. Zabalza, 346 F.3d 1255, 1259 (10th Cir. 2003) (citing United States v. Morin, 949 F.2d 297, 300 (10th Cir. 1991)).

3. United States v. Wald, 216 F.3d 1222, 1226 (10th Cir. 2000) (citing United States v. Nielsen, 9 F.3d 1487, 1491 (10th Cir. 1993); United States v. Downs, 151 F.3d 1301, 1303 (10th Cir. 1998); United States v. Parker, 72 F.3d 1444, 1450 (10th Cir. 1995)).

4. 9 F.3d 1487 (10th Cir. 1993). 
cases that relied on the Nielsen holding eventually solidified a rigid legal framework and developed a justification based on constitutional principles. Because Nielsen was driven by a particular outcome rather than legal analysis, the Tenth Circuit should follow other federal circuits and discard its unique distinction between the odors of burnt and raw marijuana. $^{5}$

This Comment develops in five parts. Part II provides a historical and contextual backdrop to probable cause and the automobile exception to the general warrant requirement of the Fourth Amendment. Part III provides a closer look at the development of the Tenth Circuit's unique rule, which will be contrasted in Part IV with the rationales of other federal circuits. Finally, in Part V, the constitutional justifications for this particular principle will be unraveled and the true motive behind the holding in Nielsen will be exposed.

\section{BACKGROUND}

\section{A. Definition of Probable Cause}

Sixty years ago, the United States Supreme Court constructed a "legal definition" of probable cause in Brinegar v. United States. ${ }^{6}$ Yet probable cause remains an elusive concept with no applicable litmus test. $^{7}$ Over time, the Court has sought to establish guidelines that both law-enforcement officers and lower courts might apply to probable-cause determinations. Generally, a search or seizure under the Fourth Amendment requires the issuance of a warrant based upon probable cause, though exceptions exist. ${ }^{8}$ In Brinegar, the Court noted that the probable-cause standard is a "practical, nontechnical conception," that turns on "the factual and practical considerations of everyday life on

5. See, e.g., United States v. McSween, 53 F.3d 684, 687, 689 (5th Cir. 1995) (finding that the smell of burnt marijuana is sufficient to establish probable cause to search the engine compartment of an automobile); United States v. Caves, 890 F.2d 87, 91 (8th Cir. 1989) (finding that the smell of burnt marijuana is sufficient to establish probable cause to search the trunk of an automobile).

6. 338 U.S. 160, 175-76 (1949); Hugo M. Mialon \& Sue H. Mialon, The Effects of the Fourth Amendment: An Economic Analysis, 24 J.L. ECON. \& ORG. 22, 23 n.2 (2008).

7. Corr, supra note 1 , at 17.

8. U.S. CONST., amend. IV; see David E. Steinberg, The Uses and Misuses of Fourth Amendment History, 10 U. PA. J. ConsT. L. 581, 584 (2008) ("The Justices [of the United States Supreme Court] have concluded that the Fourth Amendment demonstrates a 'strong preference for searches conducted pursuant to a warrant." However, the Justices have found "a few limited exceptions to this general rule." (citations omitted)).

9. Brinegar, 338 U.S. at 176 . 
which reasonable and prudent men, not legal technicians, act." 10 Throughout early case law, the Court consistently characterized probable cause as a determination based upon the information "within the knowledge of the officer." 11

Armed with these rather vague standards, lower courts struggled with their application to similar yet subtly different fact patterns, specifically when officers relied on information provided by third-party informants. In response, the Supreme Court adopted the Aguilar ${ }^{12}$ Spinelli ${ }^{13}$ test, which laid out two basic requirements for an individual seeking a warrant: he must (1) reveal his "basis of knowledge"- how he came into possession of the information; and (2) demonstrate facts sufficient to establish the "veracity" of his claims. ${ }^{14}$ Aguilar-Spinelli provided a rigorous approach for obtaining a warrant. ${ }^{15}$

A decade later in Illinois v. Gates ${ }^{16}$ the Court rejected the strict structure of Aguilar-Spinelli. ${ }^{17}$ It reasoned that probable-cause determinations are better suited by use of a flexible approach rather than a rigid framework. ${ }^{18}$ The Court harked back to the probable-cause principles set forth in Brinegar: "[P]robable cause is a fluid conceptturning on the assessment of probabilities in particular factual contextsnot readily, or even usefully, reduced to a neat set of legal rules."19 The Court held that each case must be determined by examining the "totality of the circumstances" from the standpoint of a reasonable lawenforcement officer. ${ }^{20}$ Those circumstances must be considered with

\footnotetext{
10. Id. at 175 .

11. Peter Erlinder, Florida v. J.L.-Withdrawing Permission to "Lie with Impunity": The Demise of "Truly Anonymous" Informants and the Resurrection of the Aguilar/Spinelli Test for Probable Cause, 4 U. PA. J. CONST. L. 1, 41 (2002).

12. Aguilar v. Texas, 378 U.S. 108, 114-15 (1964), abrogated by Illinois v. Gates, 462 U.S. 213 (1983).

13. Spinelli v. United States, 393 U.S. 410, 418-19 (1969), abrogated by Illinois v. Gates, 462 U.S. 213 (1983).

14. Marc L. Miller \& Ronald F. Wright, Leaky Floors: State Law Below Federal Constitutional Limits, 50 ARIZ. L. REV. 227, 241-42 (2008).

15. David E. Steinberg, Probable Cause, Reasonableness, and the Importance of Fourth Amendment History: A Response to Professor Arcila, 10 U. PA. J. CONST. L. 1211, 1216 (2008).

16. 462 U.S. 213 (1983).

17. Id. at 238; Salas Wasserstrom \& William J. Mertens, The Exclusionary Rule on the Scaffold: But Was it a Fair Trial?, 22 AM. CRIM. L. REV. 85, 96 (1985).

18. Chris Hutton, The Landscape of Search and Seizure: Observations on Recent Decisions From the United States Court of Appeals for the Eighth Circuit, 51 S.D. L. REV. 51, 54-55 (2006).

19. Gates, 462 U.S. at 232.

20. Michael Avery, Unreasonable Seizures of Unreasonable People: Defining the Totality of Circumstances Relevant to Assessing the Police Use of Force Against Emotionally Disturbed People, 34 Colum. Hum. RTS. L. ReV. 261, 288 (2003).
} 
regard and deference to the officer's training and experience. ${ }^{21}$ Essentially, probable cause becomes a matter of probabilities. ${ }^{22}$ In the end, "[t]he task of the issuing magistrate is simply to make a practical, common-sense decision whether, given all the circumstances set forth in the affidavit before him ... there is a fair probability that contraband or evidence of a crime will be found in a particular place.,"23

\section{B. Establishing Probable Cause Through the Odor of Narcotics}

Although probable cause cannot be reduced to a rigorous set of standards and benchmarks, the Supreme Court has a long history of permitting the distinctive odor of narcotics or other contraband to establish probable cause sufficient to issue a warrant. ${ }^{24}$

\section{Taylor v. United States}

The prohibition era produced Taylor v. United States, one of the earliest Supreme Court cases to hold that the mere odor of illegal substances can provide probable cause sufficient for a warrant to search private property. ${ }^{25}$ During an extensive investigation of a house that received numerous "complaints" 26 over a year period, prohibition agents recognized the distinct odor of whiskey emanating from inside the garage. ${ }^{27}$ Without a warrant, the agents broke the door of the garage, entered, and found alcohol. ${ }^{28}$ In overturning the subsequent conviction, the Court held that "[p]rohibition officers may rely on a distinctive odor as a physical fact indicative of possible crime; but its presence alone does not strip the owner of a building of constitutional guaranties ... against unreasonable search." 29 The Court concluded that the odor of whiskey

21. Id. (citing United States v. Arvizu, 534 U.S. 266, 273 (2002); Ornelas v. United States, 517 U.S. 690, 699-700 (1996)).

22. Brinegar v. United States, 338 U.S. 160, 175 (1949).

23. Gates, 462 U.S. at 238.

24. See Robert Fraser Miller, "I Want To Stop This Guy!" Some "Touchy" Issues Arising From Minnesota v. Dickerson, 71 N.D. L. REV. 211, 225 (1995).

25. 286 U.S. 1, 6 (1932).

26. The Court failed to elaborate about what constituted a "complaint." Id. at 5-6. However, when read in context with the background of the case, it can be inferred that the "complaints" involved allegations that Taylor used his premises as a distillery.

27. Id. at 5 .

28. Id.

29. Id. at 6 . 
provided sufficient probable cause to obtain a warrant; but because the agents failed to obtain one, they violated the Fourth Amendment. ${ }^{30}$

\section{Johnson v. United States}

Over a decade later, another defendant sought the suppression of evidence under the Taylor analysis in Johnson v. United States. ${ }^{31}$ Based upon a confidential informant's tip that "unknown persons were smoking opium," federal narcotics agents positioned themselves outside defendant Johnson's hotel room. ${ }^{32}$ They immediately recognized a "strong odor of burning opium which to them was distinctive and unmistakable.",33 Without any additional knowledge about the occupants, the lawenforcement officers knocked and when Johnson opened the door, they placed her under arrest and searched the hotel room, which turned up narcotics and narcotics paraphernalia. ${ }^{34}$

Johnson's appeal "erroneously" contended that, based on Taylor $v$. United States, "odors cannot be evidence sufficient to constitute probable" cause. ${ }^{35}$ Erroneous, as the Court noted, because the Taylor decision "held only that odors alone do not authorize a search without $[a]$ warrant." $"$ Despite the clear factual basis of probable cause, the Court reversed Johnson's conviction due to the officers' failure to secure a proper warrant, which made their search of the hotel room and arrest of Johnson unreasonable under the Fourth Amendment. ${ }^{37}$ With this decision, the Court settled the debate on whether odor constitutes sufficient evidence for probable cause, stating:

If the presence of odors is testified to before a magistrate and he finds the affiant qualified to know the odor, and it is one sufficiently distinctive to identify a forbidden substance, this Court has never held such a basis insufficient to justify issuance of a search warrant. Indeed it might very well be found to be evidence of most persuasive character. $^{38}$

30. Id.

31. 333 U.S. 10 (1948).

32. Id. at 12 .

33. Id.

34. $I d$.

35. Id. at 13 .

36. Id. (emphasis added).

37. Id at 15-16; James J. Tomkovicz, Hudson v. Michigan and the Future of Fourth Amendment Exclusion, 93 IowA L. REV. 1819, 1842 n.115 (2008).

38. Johnson, 333 U.S. at 13 (emphasis added). 
Under Johnson and Taylor, the recognition of a distinctive odor alone provides a sufficient probable-cause basis for a magistrate to issue a search warrant.

\section{Automobile Exception to the Warrant Requirement}

Warrantless searches are presumptively unreasonable. ${ }^{39}$ However, there are a number of "specifically established and well-delineated exceptions" to this rule. ${ }^{40}$ One long standing exception is for automobiles. ${ }^{41}$ Carroll v. United States held that "automobile[s] or other vehicle[s] may be searched" by law enforcement officers "without a warrant." ${ }^{42}$ In Carroll, the Court based its decision, in part, on a historical understanding of the need for a search warrant. At the time of adoption of the Fourth Amendment, Congress recognized

a necessary difference between a search of a store, dwelling house, or other structure in respect of which a proper official warrant readily may be obtained and a search of a ship, motor boat, wagon, or automobile for contraband goods, where it is not practicable to secure a warrant, because the vehicle can be quickly moved out of the locality or jurisdiction in which the warrant must be sought.

Yet, the Carroll decision placed limits on law enforcement's exercise of the automobile exception: (1) "In cases where the securing of a warrant is reasonably practicable, it must be used" warrant is not practicable, officers must still demonstrate to the court the requisite level of probable cause needed to obtain a warrant. ${ }^{45}$

Though Carroll created the automobile exception to the warrant requirement, it failed to sufficiently delineate the scope of a permissible search under the automobile exception. ${ }^{46}$ Clarification came in United

39. David E. Steinberg, An Original Misunderstanding: Akhil Amar and Fourth Amendment History, 42 SAN DIEGO L. REV. 227, 231 (2005) (quoting United States v. Karo, 468 U.S. 705, 717 (1984)).

40. Mincey v. Arizona, 437 U.S. 385, 390 (1978) (quoting Katz v. United States, 389 U.S. 347, 357 (1967)).

41. Thomas B. McAffee et al., The Automobile Exception in Nevada: A Critique of the Harnisch Cases, 8 NEV. L.J. 622, 623 (2008) ("Well over seventy-five years ago, the United States Supreme Court recognized the automobile exception to the warrant requirement." (citing Carroll v. United States, 267 U.S. 132, 147 (1925))).

42. 267 U.S. 132,153 (1925).

43. Id.

44. Id. at 156 .

45. Id.

46. See George M. Dery III, Improbable Cause: The Court's Purposeful Evasion of a 
States v. Ross, where the Court held that law enforcement "may conduct a search of the vehicle that is as thorough as a magistrate could authorize in a warrant 'particularly describing the place to be searched." ",47 In Ross, a law-enforcement officer received a detailed tip from a reliable informant regarding an individual dealing drugs out of an automobile. ${ }^{48}$ Acting on that tip, detectives encountered a man whose appearance and automobile matched the description provided. ${ }^{49}$ The officers stopped the vehicle and immediately searched it after noticing a bullet on the front seat. $^{50}$ The search revealed a handgun in the glove compartment and heroin in a brown paper bag. ${ }^{51}$ A more thorough search at the police station uncovered a large amount of cash in a zippered bag located in the trunk. ${ }^{52}$

On appeal, Ross challenged the warrantless search of the containers within his automobile. ${ }^{53}$ Relying on United States $v$. Chadwick ${ }^{54}$ and Arkansas v. Sanders, ${ }^{55}$ the D.C. Circuit reversed the conviction, concluding it was unreasonable for police to open containers found in the trunk without a warrant. $^{56}$ The Supreme Court disagreed and distinguished both Chadwick and Sanders because in neither case "did the police have probable cause to search the vehicle or anything within it" except the luggage in question. ${ }^{57}$ Thus, neither Chadwick nor Sanders is an "automobile case" 58 and they do not limit the scope of the automobile exception to the warrant requirement. ${ }^{59}$

The Court used the Ross decision to evaluate the scope of a warrantless search of the compartments and containers of an automobile. Carroll, it noted, "'merely relaxed the requirements for a warrant," "60 but did not adjust the scope of a search based on probable cause:

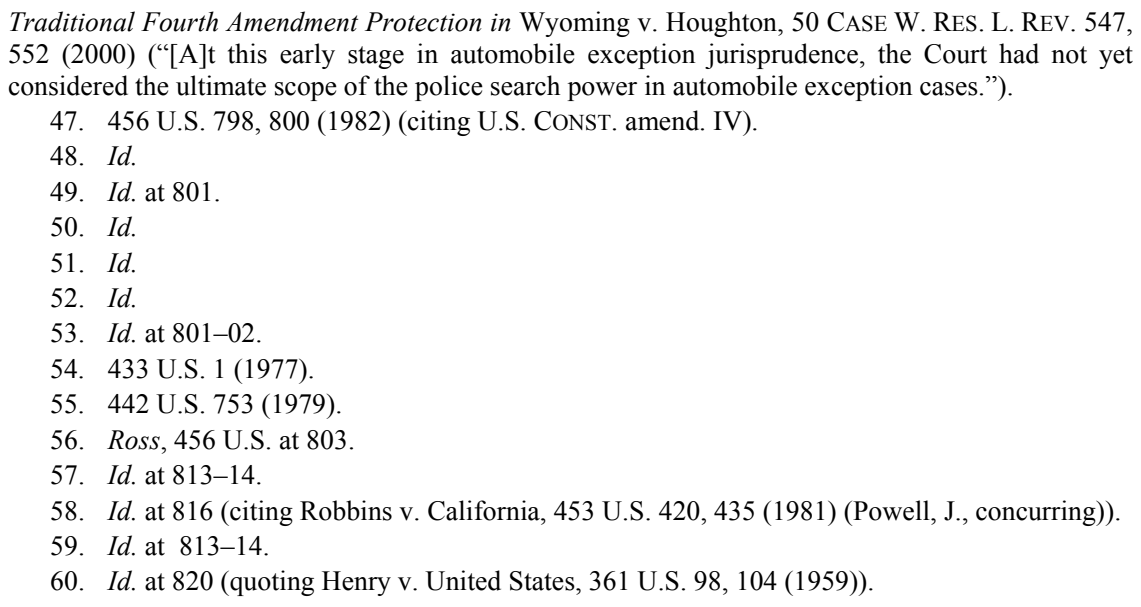


A warrant to search a vehicle would support a search of every part of the vehicle that might contain the object of the search. When a legitimate search is under way, and when its purpose and its limits have been precisely defined, nice distinctions between closets, drawers, and containers, in the case of the home, or between glove compartments, upholstered seats, trunks, and wrapped packages, in the case of a vehicle, must give way to the interest in the prompt and efficient completion of the task at hand. ${ }^{61}$

Therefore, a warrantless search of an automobile based on probable cause justifies a search to the extent allowed by a warrant. In conclusion, the Court stated, "[i]f probable cause justifies the search of a lawfully stopped vehicle, it justifies the search of every part of the vehicle and its contents that may conceal the object of the search."62 The Supreme Court's conclusion in Ross is particularly relevant to the discussion of the sufficiency of marijuana odor to establish probable cause because it suggests there is no limit to a permissible search of an automobile. However, relying on Ross, the Tenth Circuit counter-intuitively limited the scope of a warrantless search based on probable cause derived from the odor of burnt marijuana to certain parts of a vehicle. ${ }^{63}$

\section{The Odor of Marijuana as Probable Cause}

\section{Raw Marijuana}

With the strong precedent of Johnson (opium) and Taylor (alcohol), the Supreme Court had no trouble extending the doctrine to other narcotics, including marijuana. Directly on point is United States $v$. Johns ${ }^{64}$ where the Court expressly stated: "After the officers came closer and detected the distinct odor of marihuana, they had probable cause to believe that the vehicles contained contraband." ${ }^{65}$ Johns dealt with federal agents investigating a smuggling ring and their ability to detect the odor of raw marijuana. ${ }^{66}$ As such, most jurisdictions recognize that probable cause may be established by the detection of the odor of marijuana by a trained police officer. ${ }^{67}$

\footnotetext{
61. Id. at 821 (emphasis added).

62. Id. at 825 (emphasis added).

63. United States v. Nielsen, 9 F.3d 1487, 1491 (10th Cir. 1993).

64. 469 U.S. 478 (1985).

65. Id. at 482 .

66. Id. at $480-81$.

67. John M. Burkoff, Bad Faith Searches, 57 N.Y.U. L. REV. 70, 85 (1982).
} 


\section{Burnt Marijuana}

The use of marijuana smoke as probable cause for an automobile search first appeared in Robbins $v$. California. ${ }^{68}$ Highway patrol officers stopped a station wagon for erratic driving and, when the defendant opened the door, the officers smelled marijuana smoke. ${ }^{69}$ Based on that observation, the officers searched the driver and the passenger compartment of the vehicle, and found an unspecified amount of marijuana. ${ }^{70}$ They then opened the back hatch of the station wagon and discovered two opaque packages; the officers unwrapped the packages and found marijuana. ${ }^{71}$ The Supreme Court overturned the subsequent conviction, holding that the officers needed a warrant to open the containers found in the vehicle. ${ }^{72}$ Nevertheless, the Court found the initial search of the station wagon, based upon the smell of burnt marijuana, to be "lawful."" United States v. Ross, decided one year later, reversed Robbins, finding that when lawfully searching an automobile, any containers within the automobile may be legally searched if probable cause supports a belief that the container contains contraband. $^{74}$ Even after Ross cast doubt on the holding, Robbins can arguably be viewed as valid authority for permitting probable-cause determinations based solely upon the smell of marijuana smoke because the Ross opinion only addressed the issue of searching closed containers and not the underlying probable cause. ${ }^{75}$

\section{E. Odor of Burnt Marijuana as Probable Cause-Universal Acceptance}

Based on the principles set forth in Robbins, the odor of burnt marijuana became a sufficient benchmark for a probable-cause determination in lower courts. A minority of the state courts that have considered the issue still refuse to adopt this position. ${ }^{76}$ The Third

\footnotetext{
68. 453 U.S. 420 (1981), overruled by United States v. Ross, 456 U.S. 798 (1982).

69. Id. at 422 .

70. Id.

71. Id.

72. Id. at $428-29$.

73. Id. at 428 (noting that the search was "lawful" without discussing what specifically gave probable cause).

74. 456 U.S. 798, 824-25 (1982).

75. See id.; United States v. Turner, 119 F.3d 18, 21 (1997) ("The Robbins Court, however, did not question the officers' authority to open the station wagon's luggage compartment in the first place.").

76. See State v. Schmadeka, 38 P.3d 633, 638 ((Id. App. 2001) ("Thus we conclude ... that the odor of burnt marijuana alone, when recognized by a person or canine qualified to recognize the
} 
Circuit recently affirmed this principle declaring: "It is well settled that the smell of marijuana alone, if articulable and particularized, may establish not merely reasonable suspicion, but probable cause." 77 While this broad statement potentially covers all forms of marijuana, in this particular case the Third Circuit referred specifically to probable cause established when an officer smelled marijuana smoke. ${ }^{78}$ Several other circuits expressly stated a similar conclusion. ${ }^{79}$ As a practical matter, courts tend not to specifically distinguish between burnt and raw marijuana ${ }^{80}$ Both indicate the presence of contraband or illegal activity. Either way, the distinct odor of marijuana establishes probable cause.

\section{DEVELOPMENT OF THE BURNT VERSUS RAW MARIJUANA DISTINCTION WITHIN THE TENTH CIRCUIT}

The Tenth Circuit established a "common-sense" distinction between the permissible scope of a warrantless search when probable cause is based on the odor of burnt versus raw marijuana. ${ }^{81}$ The smell of burnt marijuana provides justification only for a search of the passenger compartment of a vehicle, but if an officer detects the odor of raw marijuana, he or she may permissibly search the trunk of the vehicle as well. ${ }^{82}$ Only if corroborating evidence develops upon search of the passenger compartment combined with the smell of burnt marijuana is there justification to search the trunk according to the Tenth Circuit. ${ }^{83}$ Corroborating evidence would include any amount of narcotics or related paraphernalia.

odor, is only sufficient to establish probable cause for a warrantless search of the portion of the automobile associated with that odor."); Ronald Richards, Note, The Nose Knows the Legal Accuracy of the Nose: People v. Taylor, 16 T.M. COOLEY L. REV. 323, 338-40 (1999) ("Montana is the only state [of the thirty states analyzed] that has consistently held that the odor of burned marijuana, by itself, is insufficient for probable cause to search a vehicle." (emphasis added)). But see People v. Hilber, 269 N.W.2d 159, 166 (Mich. 1978) ("We conclude that the odor of smoked marijuana does not provide probable cause for a search of an automobile...."), abrogated by People v. Kazmierczak, 607 N.W.2d 667, 675 n.13 (Mich. 2000).

77. United States v. Ramos, 443 F.3d 304, 308 (3d Cir. 2006).

78. Id. at 306 ("Officer Huertas [] testified that when he got to within three to four feet of the passenger side of the Honda, he smelled 'marijuana smoke' through his open window.").

79. Richards, supra note 76, at 338 ("Additionally, courts in the Fourth, Fifth, Eighth, and Tenth Circuits have "expressly held that the smell of burnt marijuana alone is probable cause for a warrantless search of a motor vehicle." (footnote omitted)).

80. See id. ("Moreover, the Sixth and Seventh Circuit [sic] have made similar holdings, without distinguishing "between the odors of burnt, burning, or unburned marijuana."' (citations omitted)).

81. United States v. Wald, 216 F.3d 1222, 1226 (10th Cir. 2000).

82. Id. at 1228 .

83. Id. at 1226; Brett Geiger, Comment, People v. Caballes: An Analysis of Caballes, the History of Sniff Search Jurisprudence, and its Future Impact, 26 N. ILL. U. L. REV. 595, 612 (2006). 
Although more recent case law establishes this distinction as a bright line rule ${ }^{84}$ the rule actually developed slowly. In fact, the Eighth Circuit interpreted an early Tenth Circuit decision as standing for the proposition that the smell of burnt marijuana alone provides probable cause for a warrantless search of a vehicle. ${ }^{85}$ A later Eighth Circuit case, relying upon that precedent, stated the smell of burnt marijuana provides probable cause to search the "entire vehicle." ${ }^{\prime 6}$ As discussed below, the discrepancy results from a differing application of Ross. Often, Ross is viewed as expanding upon the permissible scope of a search under the automobile exception. ${ }^{87}$ Instead, the Tenth Circuit, determined to derive a particular outcome, sought to bolster its decision with Fourth Amendment jurisprudence by using Ross as a way to narrow the permissible scope of a search. Understanding the legal reasoning behind the Tenth Circuit's current bright line rule requires a thorough review of the rule's history.

\section{A. The Beginning}

It is undisputed in the Tenth Circuit that the odor of marijuana alone can establish probable cause for a warrantless search of a vehicle. ${ }^{88}$ This rule is not surprising in light of the Supreme Court's decisions in Taylor and Johnson. The Tenth Circuit diverges from other federal circuits, however, on which areas of an automobile may be searched without a warrant once an officer smells burnt marijuana. Beginning with United

84. See Wald, 216 F.3d at 1226 ("[A]lthough the smell of burnt marijuana emanating from a vehicle provides probable cause to search the passenger compartment of that vehicle ... probable cause to search the trunk of the vehicle does not exist."); United States v. Downs, 151 F.3d 1301, 1303 (10th Cir. 1998) (Based on the smell of burnt marijuana, "there is no fair probability that the trunk of the car contains marijuana and an officer must limit the search to the passenger compartment.").

85. See United States v. Caves, 890 F.2d 87, 90 (8th Cir. 1989) ("Many lower courts have relied primarily upon the odor of marijuana in determining that probable cause existed for a warrantless automobile search.”) (citing United States v. Loucks, 806 F.2d 208 (10th Cir. 1986) (The officer smelled "what he thought was still-burning marijuana.")).

86. United States v. Neumann, 183 F.3d 753, 756 (8th Cir. 1999).

87. Edwin Butterfoss, As Time Goes By: The Elimination of Contemporaneity and Brevity as Factors in Search and Seizure Cases, 21 HARV. C.R.-C.L. L. REV. 603, 618 (1986); A. Michael Froomkin, The Metaphor is the Key: Cryptography, the Clipper Chip, and the Constitution, 143 U. PA. L. REV. 709, 872-73 n.716 (1995); Steven D. Clymer, Note, Warrantless Vehicle Searches and the Fourth Amendment: The Burger Court Attacks the Exclusionary Rule, 68 CORNELL L. REV. 105, 131-33 (1983).

88. See United States v Morin, 949 F.2d 297, 300 (10th Cir. 1991) ("[T]he odor of marijuana alone can satisfy the probable cause requirement to search a vehicle or baggage."); United States v. Merryman, 630 F.2d 780, 785 (10th Cir. 1980) ("Once the agent smelled the marijuana, he was certainly justified in the search of the entire truck."). 
States v. Loucks, the Tenth Circuit upheld a search of an automobile based solely on the officer's recognition of the odor of burnt marijuana. ${ }^{89}$ With probable cause established, the officer began a search of the passenger compartment, which revealed a small amount of marijuana. ${ }^{90}$ He then opened the trunk and found an additional twenty-five pounds of marijuana inside a laundry bag. ${ }^{91}$ In denying the defendant's motion to suppress the district court relied on United States $v$. Ross, invoking the principle that when probable cause supports the search of an automobile, the officer " "may conduct a warrantless search of the car and the containers within it that could conceal the object of the search." "92 The Tenth Circuit upheld the district court's decision without discussion of whether the smell of burnt marijuana alone provided justification to search the trunk. ${ }^{93}$ Because the officer found corroborating evidencethe small amount of narcotics - before searching the trunk, the Tenth Circuit did not specifically address whether the odor of burnt marijuana justified a search of the trunk.

\section{B. Personal-Use Doctrine}

In Loucks, the Tenth Circuit addressed another pressing question relevant to this discussion. Loucks argued that the small amount of marijuana found within the passenger compartment of his vehicle indicated personal use, not narcotics trafficking or distribution. ${ }^{94}$ Therefore, he claimed, the presence of a small amount of narcotics established probable cause to search the passenger compartment, but not the trunk. ${ }^{95}$

In United States v. Burnett, the Sixth Circuit addressed the same argument - that the small amount of marijuana found within the passenger compartment of his automobile indicated that the defendant was "only a casual user of narcotics as opposed to a dealer." 96 As a response, the Sixth Circuit stated that imposing such a rule

burden[s] the police with having to make another judgment callwhether a certain amount of marijuana, cocaine, or other drug found on

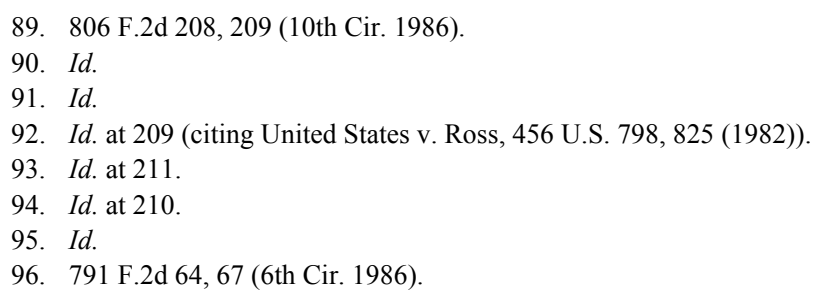


a person or in some container makes the person a casual user or a dealer. Determining the existence of probable cause to search on the amount of contraband initially found is a line which need not and should not be drawn .... From the long history of litigated drug cases, it is evident that neither the casual user nor the dealer fits any precise description or category.

In other words, the Sixth Circuit rejected the argument that there should be a distinction between casual users and narcotics traffickers when determining the existence of probable cause. ${ }^{98}$

The Tenth Circuit concurred with the Sixth Circuit's analysis and refused to adopt a personal-use doctrine, arguing it was "illogical and unreasonable." 99 Other circuits have reached similar conclusions in refusing to adopt a personal-use doctrine. ${ }^{100}$ Despite this initial rejection of a rule requiring officers to make a determination between drug use and drug trafficking, this concept has been revived by the Tenth Circuit to support its distinction between burnt and raw marijuana for the purposes of searching an automobile. ${ }^{101}$

\section{An Uncertain Future: How Other Courts Interpreted Loucks}

Based partially on the Loucks decision, the Eighth Circuit determined that burnt marijuana alone provides probable cause to search an automobile, without distinction between the passenger compartment and the trunk. ${ }^{102}$ As previously noted, other circuits and commentators interpreted Loucks and its progeny as permitting a warrantless search of an automobile's trunk based solely on the odor of burnt marijuana. ${ }^{103}$

97. Id. (emphasis added).

98. Id. at n.2.

99. Loucks, 806 F.2d at 210.

100. See United States v. Turner, 119 F.3d 18, 20 (D.C. Cir. 1997) ("Those federal courts that have considered the 'personal use' argument have rejected it ....").

101. See United States v. Wald, 216 F.3d 1222, 1226 (10th Cir. 2000) ("[T]he smell of burnt marijuana is indicative of drug usage, rather than drug trafficking ....").

102. See United States v. Neumann, 183 F.3d 753, 756 (8th Cir. 1999) ("[D]etection of the smell of burnt marijuana ... gave him probable cause to search the entire vehicle for drugs."); United States v. Caves, 890 F.2d 87, 91 (8th Cir. 1989) ("[W]e are unable to conclude that the odor of burnt marijuana on Cave's breath and person, when considered in the context of the circumstances confronting the trooper, was insufficient to establish probable cause for the search of the automobile.").

103. See Caves, 890 F.2d at 90 ("Many lower courts have relied primarily upon the odor of marijuana in determining that probable cause existed for a warrantless automobile search." (interpreting United States v. Loucks, 806 F.2d 208 (10th Cir. 1986), in which the officer smelled "still-burning marijuana")); Richards, supra note 76, at 338 (The Tenth Circuit has "“expressly held that the smell of burnt marijuana alone is probable cause for a warrantless search of a motor 
Post-Loucks, other Tenth Circuit cases addressed searches of automobiles after the officer detected the odor of burnt marijuana, but those subsequent cases involved either consent or corroborating evidence prior to a search of the trunk. ${ }^{104}$ Then, in United States $v$. Nielsen, ${ }^{105}$ the Tenth Circuit took a large step toward establishing a distinction between the odors of burnt and raw marijuana.

D. Distinguishing Between Burnt and Raw Marijuana: United States v. Nielsen

1. Facts

Officer Bushnell stopped the defendant's vehicle for speeding. ${ }^{106}$ When the officer approached the open window, he "immediately recognized the smell of burned marijuana" emanating either from the defendant or from the automobile itself. ${ }^{107}$ The defendant, Nielsen, consented to a search of the passenger compartment, which revealed no contraband of any kind. ${ }^{108}$ A routine radio check then revealed that Nielsen had been arrested for misdemeanor marijuana possession almost fifteen years prior. ${ }^{109}$ Officer Bushnell then searched the vehicle's trunk without a warrant or Nielsen's consent and discovered a set of scales and two kilograms of cocaine. ${ }^{110}$

Officer Bushnell's search uncovered neither evidence of marijuana nor any marijuana-related paraphernalia. ${ }^{111}$ In support of his motion to suppress the evidence uncovered in the search, Nielsen introduced "the negative results of a urine test that should have indicated whether he had used marijuana within the time frame of the stop" to refute Officer Bushnell's claim that the odor of burnt marijuana was present. ${ }^{112}$ The district court, however, found Officer Bushnell's testimony about the odor of burnt marijuana credible. ${ }^{113}$ Applying Loucks ${ }^{114}$ and Ross, ${ }^{115}$ the

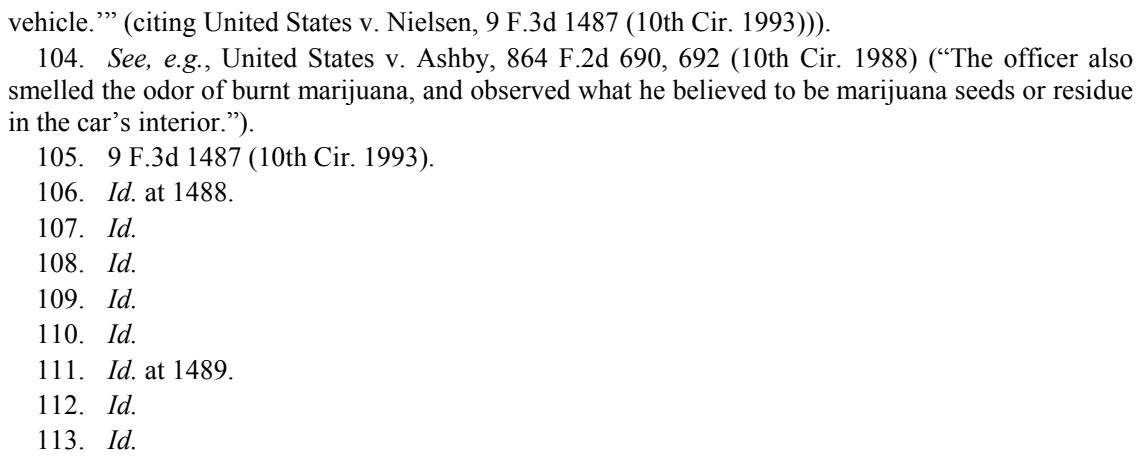


court denied Nielsen's motion to suppress, reasoning that probable cause permits a warrantless search of every part of a vehicle, including the trunk. $^{116}$

\section{Analysis}

Considering Nielsen's appeal, the Tenth Circuit noted its obligation to "accept the trial court's findings of fact unless they are clearly erroneous."117 Despite this obligation, the Tenth Circuit struggled to reconcile the fact pattern presented:

The rational explanations for these incongruous facts suggest the following possibilities: (1) Bushnell did smell marijuana-someone else had recently smoked marijuana in defendant's car, or, less likely, defendant had smoked marijuana in the car, disposed the remains out the window, and the urine test result was invalid; (2) Bushnell thought he smelled marijuana, but was mistaken; or (3) Bushnell fabricated his testimony that he detected the smell of marijuana. The district court believed the officer's testimony, thus, apparently it accepted the first possibility. Based upon the cold record we would not have made the same determination; but, as is the case with essentially all factual findings based upon credibility, we cannot hold that the district court's factual finding is clearly erroneous. ${ }^{11}$

While the Tenth Circuit purported to accept the district court's factual findings, it expressly rejected the lower court's legal analysis.

The court distinguished both Loucks and United States v. Ashby, ${ }^{119}$ another Tenth Circuit case where an officer used the smell of burnt marijuana as probable cause to search an automobile, ${ }^{120}$ "because in those cases the officers not only detected the odor of burnt marijuana, they also found marijuana in the passenger compartment before searching the trunk."121 Unlike the district court, the Tenth Circuit viewed Ross as limiting the scope of a warrantless search to "the places

114. 806 F.2d 208, 209 (10th Cir. 1986) (Where "an officer legitimately stops a car, and has probable cause to believe drugs are concealed in that car, he may conduct a warrantless search of the car and the containers within it that could conceal the object of the search.").

115. 456 U.S. 798, 825 (1982) ("If probable cause justifies the search of a lawfully stopped vehicle, it justifies the search of every part of the vehicle and its contents that may conceal the object of that search.").

116. Nielsen, 9 F.3d at 1489

117. Id. (citing United States v. Pena, 920 F.2d 1509, 1514 (10th Cir. 1999)).

118. Id. (footnote omitted) (emphasis added).

119. 864 F.2d 690 (10th Cir. 1988).

120. Id. at 692 .

121. Nielsen, 9 F.3d at 1490. 
in which there is probable cause to believe that [the object of the search] may be found." "22 Therefore, it concluded that an odor of burnt marijuana suggests only that "the passenger compartment might contain marijuana," and does not establish a "fair probability that the trunk [might] contain[] marijuana." "23 The decision went so far as to conclude that, based solely upon the odor of burnt marijuana, no disinterested magistrate would issue a search warrant for anything other than the passenger compartment. ${ }^{124}$

As further support for its distinction, the Tenth Circuit turned to the Supreme Court's decision in California v. Acevedo, ${ }^{125}$ stating that "if the object of the search is a paper bag of marijuana in the trunk, and police do not have probable cause to believe the object of the search is hidden elsewhere, a search of the entire vehicle would be unreasonable." ${ }^{\prime 26}$ Acevedo, the Tenth Circuit determined, reaffirmed the limiting nature of the rule provided by Ross. ${ }^{127}$ After applying Ross, the Tenth Circuit overturned the district court's denial of Nielsen's motion to suppress. ${ }^{128}$

\section{E. The Aftermath: Further Developments in the Nielsen Progeny}

In the wake of Nielsen, the Tenth Circuit continued to apply its holding without further analysis or justification for the clear distinction between burnt and raw marijuana. ${ }^{129}$ Not until United States v. Downs ${ }^{130}$ did the Tenth Circuit elaborate on its strikingly unique rationale. In Downs, the Tenth Circuit "recognize[d] that the smell of burnt marijuana is generally consistent with personal use of marijuana in the passenger compartment," whereas if the odor is of raw marijuana, "there is a fair probability that the car is being used to transport large quantities of marijuana and that the marijuana has been secreted in places other than the passenger compartment.",131

\footnotetext{
122. Id. at 1491 (quoting United States v. Ross, 456 U.S. 798, 824 (1982)).

123. Id.

124. Id.

125. 500 U.S. 565 (1991).

126. Nielsen, 9 F.3d at 1491 (citing California v. Acevedo, 500 U.S. 565, 580 (1991)).

127. Id.

128. Id.

129. See United States v. Parker, 72 F.3d 1444, 1450 (10th Cir. 1995) ("The odor of marijuana in the passenger compartment of a vehicle does not, however, standing alone, establish probable cause to search the trunk of the vehicle.") (citing Nielsen, 9 F.3d at 1491).

130. 151 F.3d 1301 (10th Cir. 1998).

131. Id. at 1303.
} 
The holding in Downs reopened the issue of whether to distinguish between the presence of narcotics that indicates personal use and that which indicates trafficking. Finally, in United States v. Wald, ${ }^{132}$ the Tenth Circuit solidified this distinction:

This rule is premised on the common-sense proposition that the smell of burnt marijuana is indicative of drug usage, rather than drug trafficking, and because it is unreasonable to believe people smoke marijuana in the trunks of cars, the mere smell of burnt marijuana does not create the fair probability that the trunk contains marijuana. ${ }^{133}$

Wald dealt with the odor of burnt methamphetamine rather than marijuana, ${ }^{134}$ but the same principles set forth in Nielsen, Parker, and Downs applied. Despite the Tenth Circuit's early reluctance to establish a personal-use doctrine to limit the permissible scope of an automobile search when small amounts of narcotics are discovered, ${ }^{135}$ almost two decades later, the Tenth Circuit had no hesitation in applying a personaluse limit to probable cause established by the distinctive odor of narcotics.

\section{An Alternative Rationale: How Other Circuits Reached A DIFFERENT CONCLUSION}

In rendering its judgment in Nielsen, the Tenth Circuit acknowledged that at least one other circuit potentially disagreed with its holding: "The only other case we have uncovered finding probable cause when the smell was not corroborated by the search was United States $v$. Reed ...."136 Reed involved a search of a locked compartment within an automobile based on nothing but the officer's detection of the odor of burnt marijuana. ${ }^{137}$ That search did not reveal any evidence of marijuana or related paraphernalia; ${ }^{138}$ yet, the Fifth Circuit found the search to be reasonable. ${ }^{139}$ It reasoned that officers recognized "the distinct odor of burnt marihuana, and this in itself would have justified the subsequent

\footnotetext{
132. 208 F.3d 902 (10th Cir. 2000).

133. Id. at 905 (emphasis added).

134. Id. at 904 .

135. United States v. Loucks, 806 F.2d 208, 210-11 (10th Cir. 1986) (rejecting a personal-use theory for drugs discovered in the passenger compartment of an automobile).

136. United States v. Nielsen, 9 F.3d 1487, 1491 n.5 (10th Cir. 1993) (emphasis added).

137. United States v. Reed, 882 F.2d 147, 148 (5th Cir. 1989).

138. The search did reveal over four pounds of cocaine. Id.

139. Id. at $148-49$.
} 
search of Reed's vehicle. ... including the locked compartment that was a likely place to conceal contraband." 140 The court also noted that "[i]t is not controlling that the substance eventually discovered in the vehicle was cocaine, and that no marihuana was ever found. It is settled that the presence or absence of probable cause to search is not determined by what the search does or does not ultimately reveal." $" 141$

Although acknowledging the contradictory holding in Reed, the Tenth Circuit was quick to dismiss its relevance in Nielsen. First, it reasoned that in Reed the police located the locked compartment in question within the passenger compartment of the automobile, not the trunk. $^{142}$ Therefore, the Fifth Circuit's holding fit within the distinction between a trunk and a passenger compartment drawn by the Tenth Circuit in Nielsen. Next, because the Fifth Circuit used broad language in defining the scope of the search, it never actually stated whether a search of the trunk was permissible under the probable cause established. ${ }^{143}$ Finally, even if one might interpret the Reed decision as a direct contradiction to the principles of Nielsen, a Fifth Circuit case is not controlling within the Tenth Circuit. No obligation exists to follow, or even consider, the Fifth Circuit's conclusions. Despite the attempt by the Tenth Circuit to reconcile its holding in Nielsen with the holding of Reed, other circuits, including the Fifth, continued to disagree with the distinction between burnt and raw marijuana.

\section{A. The Fifth Circuit}

The Fifth Circuit's marquee case, in direct contradiction to the Tenth Circuit's burnt versus raw distinction, is United States v. McSween. ${ }^{144}$ The facts involved a traffic stop of the defendant during which Officers Billings and Price obtained consent from the defendant to search the passenger compartment and trunk. ${ }^{145}$ Officer Billings opened the trunk and the defendant helped him remove the interior panels. ${ }^{146}$ Meanwhile, Officer Price ran a background check and then searched the passenger

\footnotetext{
140. Id. at 149 .

141. Id.

142. United States v. Nielsen, 9 F.3d 1487, 1491 n.5 (10th Cir. 1993).

143. Id. ("The court there [in Reed] declared that the odor of marijuana alone justified a search of the entire vehicle ....").

144. 53 F.3d 684 (5th Cir. 1995).

145. Id. at 685 . The opinion does not note why officers initially wanted to search the vehicle, other than the fact that officers "[n]otice[d] a cellular phone and radar detector in the car's interior...." Id.

146. Id.
} 
area. ${ }^{147}$ This search did not reveal narcotics, but Officer Price "noticed the smell of burnt marihuana" while searching the passenger area. ${ }^{148}$ Despite the lack of corroborating evidence, and without the defendant's consent, Officer Price opened the hood of the vehicle and found a small amount of marijuana in a hole of the car's firewall. ${ }^{149}$ A subsequent search at the impound lot, following the defendant's arrest, revealed more marijuana and a "shoulder sling of crack cocaine." 150

On appeal, the Fifth Circuit disagreed with the defendant's argument that even if the odor of marijuana provided sufficient probable cause for a warrantless search, the scope of the intrusion should have been restricted to the passenger compartment of the vehicle, because that was the detected origin of the odor. ${ }^{151}$ The smell of marijuana as sufficient grounds for a finding of probable cause is firmly established in the Fifth Circuit. ${ }^{152}$ With probable cause established, an application of Ross supported the actions of Officer Price:

It is well settled that, in a case such as this, the detection of the odor of marihuana justifies "a search of the entire vehicle."... [I]f there is probable cause to suspect that the vehicle contains contraband, then the search may extend not only to closed containers, but also to a "car's trunk or glove compartment." The same reasoning applies to the area under the hood, where drugs may also be concealed.

Under this rationale, the smell of burnt marijuana in the passenger compartment established probable cause to commence a search of every part of the vehicle, including the trunk, or as in this case, the engine compartment. To put it another way, the holding permits a search for "every part of the vehicle and its contents that may conceal the object of the search." 154 This holding applied Ross in a less limiting fashion than the Tenth Circuit did in Nielsen.

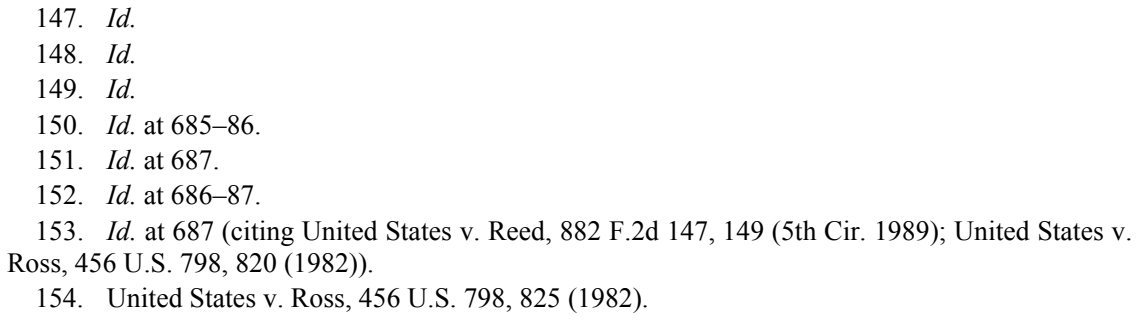




\section{B. The Eighth Circuit}

Similarly, the Eighth Circuit has disagreed with the Tenth Circuit's distinction between the odors of burnt and raw marijuana. An analysis of Eighth Circuit jurisprudence begins with United States v. Caves. ${ }^{155}$ When the defendant was stopped for speeding, he immediately exited his vehicle and approached the officer's patrol car. ${ }^{156}$ Subsequent discussion regarding the speeding violation took place within the patrol car. ${ }^{157}$ During this conversation, the officer noticed an "intense odor of burnt marijuana on Caves's person and breath" and advised the defendant that he would be conducting a search of the defendant's vehicle. ${ }^{158}$ On appeal, the Eighth Circuit upheld the search even though the officer failed to detect the odor emanating from a vehicle:

Although the odor of burnt marijuana on the driver alone is undoubtedly less probative of the existence of unused marijuana in the automobile than would be the odor of unburnt marijuana emanating from both the driver and the vehicle, we are unable to conclude that the odor of burnt marijuana on Caves's breath and person, when considered in the context of the circumstances confronting the trooper, was insufficient to establish probable cause for the search of the automobile. ${ }^{159}$

In Caves, the probable cause determination was based not on the vehicle itself but on a recent occupant. As expressed in Brinegar, probable cause is a matter of probabilities. ${ }^{160}$ Without excluding the possibility that the defendant had potentially smoked marijuana at an undisclosed location prior to entering the vehicle, the Eighth Circuit found that the automobile was a probable location where the defendant, or his passenger, smoked marijuana. ${ }^{161}$ Therefore, probable cause existed to search the vehicle.

While the Eighth Circuit never expressly stated that a search of the trunk was permissible based on the odor of burnt marijuana alone, ${ }^{162}$ later

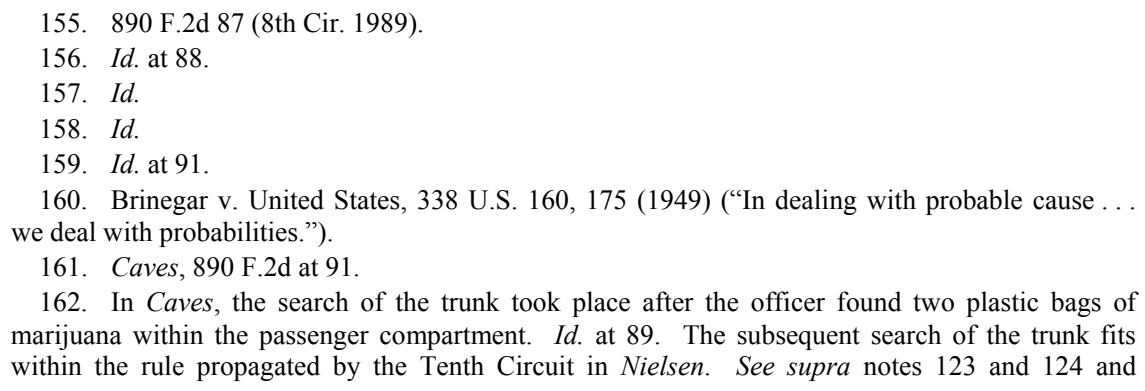

162. In Caves, the search of the trunk took place after the officer found two plastic bags of marijuana within the passenger compartment. Id. at 89 . The subsequent search of the trunk fits within the rule propagated by the Tenth Circuit in Nielsen. See supra notes 123 and 124 and 
case law clarified the intent of the Eighth Circuit. In United States $v$. Neumann, the Eighth Circuit stated that an officer's "detection of the smell of burnt marijuana ... gave him probable cause to search the entire vehicle for drugs."163 The Neumann decision lacks any requirement for corroborating evidence. Like the Fifth Circuit, the Eighth Circuit concluded that probable cause to search the vehicle includes every part of the vehicle, not simply the area of the vehicle in which the odor was detected.

The Fifth and Eighth Circuit applied the principles of Ross in a manner that expanded, rather than limited, the permissible scope of a warrantless search of an automobile. Both circuits concluded that under Ross, once officers established probable cause on a vehicle, they were authorized to search the entire vehicle. Effectively, the permissible scope of a search was an all or nothing proposition. Since the odor of burnt marijuana was sufficient probable cause, nothing under Ross requires the officers to limit their search to the passenger compartment.

\section{ANALYSIS}

The Tenth Circuit is the only federal circuit to adopt a standard that permits a search of the entire vehicle when an officer recognizes the smell of raw marijuana but simultaneously prohibits a search of any part of the vehicle other than the passenger compartment if the officer instead smells burnt marijuana. ${ }^{164}$ A close reading of Nielsen and its progeny suggests that the black letter rule outlined in Wald is not the product of legal reasoning and precedent based on Fourth Amendment jurisprudence, but rather the Nielsen Court's determination that a law enforcement officer manufactured testimony to legitimize his otherwise illegal search. With the Nielsen decision in place, the Tenth Circuit eventually solidified a framework and developed logic based on constitutional principles to support its conclusions. The rule that developed within the Tenth Circuit is, therefore, the product of resultdriven analysis - legal reasoning adopted to justify a pre-determined outcome. As support for this argument, this Comment will address: (1)

\footnotetext{
accompanying text.

163. United States v. Neumann, 183 F.3d 753, 756 (8th Cir. 1999) (emphasis added) (citing Caves, 890 F.2d at 90).

164. A minority of state court decisions also refused to uphold probable cause on the trunk of a vehicle if based solely upon an officer recognizing the odor of burnt marijuana. See sources cited supra note 76. But see Mendez v. People, 986 P.2d 275, 280 (Colo. 1999) ("[T]he smell of burning marijuana may give an officer probable cause to search or arrest." (citing People v. Baker, 813 P.2d 331, 333 (Colo. 1991))).
} 
the Tenth Circuit's faulty analysis of Ross, (2) why Nielsen and its progeny erroneously rest upon the failed and often-rejected personal use doctrine, and (3) an alternative rationale behind the Nielsen decision. Additionally, the Comment argues that the rule outlined by the Tenth Circuit in Nielsen and its progeny does little to protect the rights of individuals and concludes that this rule should be discarded.

\section{A. The Tenth Circuit's Faulty Interpretation of Ross}

Well after the ruling in Nielsen, the Tenth Circuit developed a more complex and rigid legal framework as continued support for its Nielsen progeny. But to lay a foundation for its original holding, the Tenth Circuit needed favorable Fourth Amendment precedent. The Tenth Circuit turned to the principles asserted in Ross.

1. United States v. Ross: Broadening the Permissible Scope of a

Warrantless Search Under the Automobile Exception

Originally, the rationale of the motor-vehicle exception to the warrant requirement was based upon the "inherent mobility" of an automobile, a valid exigency that supports the exception. ${ }^{165}$ However, over the years, the Court has framed the automobile exception solely as a matter of probable cause, without mentioning the underlying exigencies which gave rise to the exception in the first place. ${ }^{166}$ By the time Ross was decided, the Court had established one set of rules for an automobile and another for the containers located within the automobile. ${ }^{167}$

Ross provided the Court an opportunity to reevaluate the permissible scope of the warrantless search of an automobile and simplify this area of law by providing bright-line rules for police. ${ }^{168}$ In doing so, the Court intended to expand, rather than limit—as suggested by the Tenth Circuit - the permissible scope of a warrantless automobile search to

\footnotetext{
165. Clymer, supra note 87, at 114-15.

166. See id. at 114 (citing Texas v. White, 423 U.S. 67 (1975) (per curiam)).

167. See Arkansas v. Sanders, 442 U.S. 753, $763-64$ (1979) (requiring law enforcement to obtain a warrant before searching containers found within an automobile), abrogated by California v. Acevedo, 500 U.S. 565 (1991); United States v. Chadwick, 433 U.S. 1, 15-16 (1977) (holding that luggage or other containers seized and under the exclusive control of law enforcement may not be searched without a warrant), abrogated by California v. Acevedo, 500 U.S. 565 (1991); Carroll v. United States, 267 U.S. 132, 146-47 (1925) (establishing an exception to the warrant requirement for automobiles).

168. Clymer, supra note 87, at 106.
} 
include all containers and compartments. ${ }^{169}$ The Court noted that because criminals typically conceal contraband in containers, "the practical consequences of the Carroll decision would be largely nullified if the permissible scope of a warrantless search of an automobile did not include containers and packages found inside the vehicle."170 Ross, therefore, stands for the proposition that probable cause to search any part of an automobile grants law enforcement justification for searching every part of the vehicle. ${ }^{171}$ As a practical matter, the Court appears to be unwilling to place any limitations on the scope of the automobile exception. ${ }^{172}$ However, the Court indicated that if probable cause exists solely for a particular container within an automobile, but not for the automobile itself, then perhaps the broad scope established in Ross might fail to apply. ${ }^{173}$ That exact fact scenario was presented in California $v$. Acevedo. ${ }^{174}$

Despite the broad scope of a warrantless search permissible under the automobile exception pronounced in Ross, the Tenth Circuit managed to derive a contradictory conclusion. By viewing Ross through the lens of Acevedo, the Tenth Circuit decided that the limited holding of Acevedo represented a further limitation on searches permitted by Ross, rather than viewing it as the exception to the rule foreseen by the Ross decision. As a result of that analysis, the Tenth Circuit found Ross to stand for different principles than those determined by other circuits. The probable cause established in Acevedo extended solely to a particular container known to be in Acevedo's car. ${ }^{175}$ Therefore, the Court reasoned, the justifiable scope of the subsequent search extended only to that container. ${ }^{176}$ Based upon this dictum, Nielsen concluded that Acevedo reaffirmed the idea that Ross severely limits the areas of a vehicle that might be the object of a warrantless search. ${ }^{177}$ Essentially, the Nielsen analysis suggests that Ross requires law enforcement to establish probable cause for each individual section of an automobile (i.e. the passenger compartment, trunk, engine, etc.). ${ }^{178}$ In reaching this

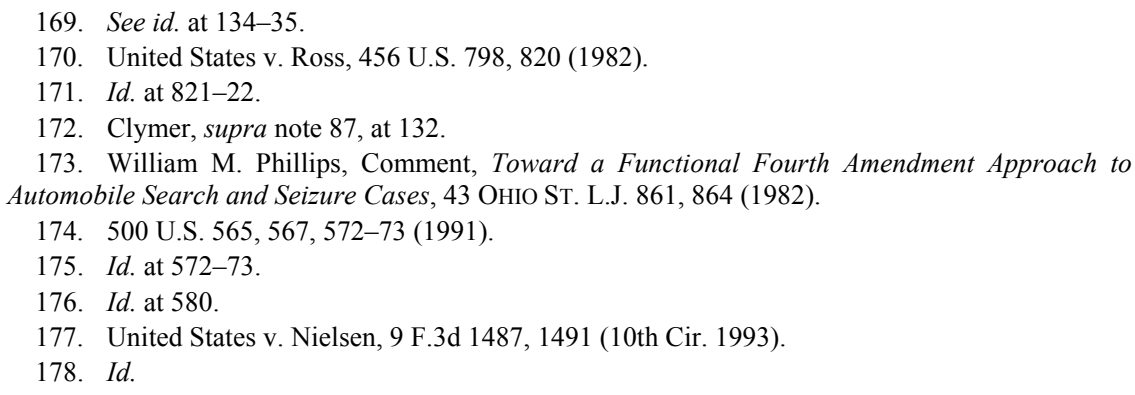


restrictive conclusion, the Tenth Circuit was quick to distinguish two of its own previous cases, Ashby and Loucks, which arguably stand for a contradictory proposition. ${ }^{179}$ Both Ashby and Loucks state, without qualification or explanation, that "[o]nce probable cause exists for a search, the police have authority to search the entire vehicle." ${ }^{\prime 80}$ This language suggests there is no independent probable-cause requirement before a search of a trunk is valid.

\section{Why Acevedo Fails to Alter the Ross Analysis}

Despite the Tenth Circuit's assertion that Acevedo reinforces the limiting nature of Ross, the Acevedo decision in fact expands the permissible scope of a warrantless search involving an automobile. The decision further "demonstrates the Court's increasing emphasis on law enforcement efficiency and evidence preservation rather than exigency." 181 Additionally, the Tenth Circuit either failed to realize or, more likely, ignored the fact that Acevedo should clearly be distinguished from the Ross holding. Acevedo is factually similar to Chadwick and Sanders - decided pre-Ross - in which the Supreme Court announced that if law enforcement established probable cause that bags or luggage conceal contraband, then it is impermissible for officers to wait until the container is loaded into an automobile in order to apply the automobile exception for a warrantless search of the container. ${ }^{182}$ As Chadwick and Sanders indicate, the Court drew a distinction between probable cause for an automobile and probable cause for a container that was subsequently placed into an automobile. ${ }^{183}$ Similarly, in Acevedo, lawenforcement officers had probable cause to believe that only a particular object contained contraband rather than the automobile in which it was contained. ${ }^{184}$ Acevedo eradicated this distinction and potentially opens the door for law-enforcement officers to establish probable cause for a particular container and use that as an excuse to search an individual's entire vehicle. ${ }^{185}$ Under that particular set of circumstances, the Court

179. Id. at 1490

180. United States v. Ashby, 864 F.2d 690, 692 (10th Cir. 1988) (citing United States v. Loucks, 806 F.2d 208, 209 (10th Cir. 1986)).

181. Shaela Ann McNulty, Comment, Constitutional Law-Fourth Amendment Protection on the Wane-California v. Acevedo, 26 SUFFOLK U. L. REv. 248, 257 (1992).

182. California v. Acevedo, 500 U.S. 565, 571-72 (1991).

183. Id. at 580 .

184. Id. at $567-68$.

185. Id. at 580 ("Until today, this Court has drawn a curious line between the search of an automobile that coincidentally turns up a container and the search of a container that coincidentally 
announced that the permissible scope of the search is properly limited only to that container because probable cause existed prior to the involvement of an automobile. ${ }^{186}$

That analysis is not applicable to the current situation because Acevedo failed to alter the Ross analysis. ${ }^{187}$ The Supreme Court in Acevedo correctly defined the scope of a warrantless search as being limited to those objects for which law enforcement can establish probable cause. But in Nielsen the Tenth Circuit incorrectly interpreted that notion as applying to the various parts of a vehicle as separate distinguishable objects which each receive an individualized probablecause analysis. However, as demonstrated in Ross, an automobile may be considered a single object and therefore a probable-cause determination may be made on the vehicle in its entirety, not on separate parts. ${ }^{188}$ The Fifth Circuit summed up the scope of a search permitted by Ross:

[I]f officers have probable cause to believe that contraband is in only one part of a car, then they are limited to that area. If, on the other hand, officers have probable cause to believe that contraband is located somewhere in a car, but they don't know exactly where, then they can search the entire vehicle.

In response, the Tenth Circuit would argue that the odor of burnt marijuana indicates only that narcotics are present in the passenger compartment-nobody smokes marijuana in the trunk-and corroborating evidence is needed to permit a search of the trunk. ${ }^{190}$ As shown infra, this narrow viewpoint runs contrary to the reality of narcotics cases.

More importantly, though, a closer reading of the particular language used by the Fifth Circuit to summarize Ross undermines the Tenth Circuit's argument. The phrase, "is in only one part," suggests that law enforcement is limited when the circumstances demonstrate that the

turns up in an automobile. The protections of the Fourth Amendment must not turn on such coincidences." (emphasis added)).

186. Id. at 574-76.

187. See id. at 580 ("Our holding today neither extends the Carroll doctrine nor broadens the scope of permissible automobile search delineated in Carroll, Chambers, and Ross.").

188. United States v. Ross, 456 U.S. 798, 823-24 (1982).

189. United States v. Seals, 987 F.2d 1102, 1107 n.8 (5th Cir. 1993). The Nielsen Court relied on this opinion in making its argument against permitting a search of the trunk. United States v. Nielsen, 9 F.3d 1487, 1491 (10th Cir. 1993). Ironically, the Fifth Circuit has most clearly stated its belief that the odor of burnt marijuana provides probable cause to search the trunk of an automobile. United States v. McdSween, 53 F.3d 684, 686-87 (5th Cir.)

190. Nielsen, 9 F.3d at 1491. 
particular section of the vehicle is the only possible location where contraband might be found, such as a situation where the officers know in advance that only a particular container conceals contraband. Otherwise, a generalized finding of probable cause on the vehicle must permit a search of every part that could contain the object of the search because there is nothing to indicate that the passenger compartment is the only part of the vehicle concealing contraband. The D.C. Circuit proposed a similar conclusion: the facts on the record in Acevedo demonstrate a complete lack of probable cause for any part of the vehicle other than the suspected bag and, additionally, that the government failed to even argue that the officers had reason to suspect the presence of additional narcotics. ${ }^{191}$ This narrow set of circumstances created the limitation set forth in Acevedo and the D.C. Circuit refused to extend the proposed limitations to cases where probable cause was established on the vehicle itself. ${ }^{192}$ It continued to utilize the broad scope permitted by the more traditional and normative reading of Ross. ${ }^{193}$

\section{Burnt Versus Raw: Rejection of the Tenth Circuit's Marijuana Distinction}

Defendants in other jurisdictions have submitted a rationale similar to the Tenth Circuit's reading of Ross as support for their own motions to suppress. Other federal courts have found the Tenth Circuit's analysis unpersuasive. ${ }^{194}$ A district court in the Third Circuit called the logic "unique" and dismissed it, stating: "[That] is not the law here."195 Probable cause on the vehicle includes the trunk, and "[a]ny contraband seized as a result of the search will be admissible even if the search provides no additional indications of marijuana use." 196 In the First Circuit, a district court considered the application of Wald, where the Tenth Circuit invalidated a warrantless search of the engine compartment when probable cause was based solely upon the odor of burnt methamphetamine. ${ }^{197}$ The district court concluded that " $\left.t\right]$ he court's

\footnotetext{
191. United States v. Turner, 119 F.3d 18, 22 (D.C. Cir. 1997) (citing California v. Acevedo, 500 U.S. $565,580(1991))$.

192. Id. at $22-23$.

193. Id.

194. Id. at 23 .

195. United States v. Nelson, No. 06-240, 2006 U.S. Dist. LEXIS 67793, at*11 (E.D. Pa. Sept. 20, 2006). Other Third Circuit district courts have adopted the reasoning of Nelson. United States v. Ushery, 526 F. Supp. 2d 497, 503 (M.D. Pa. 2007).

196. Ushery, 526 F. Supp. 2d at 502-03.

197. United States v. Pugh, 223 F. Supp. 2d 325, 330 (D. Me. 2002).
} 
conclusion in Wald is difficult to reconcile" with earlier Tenth Circuit precedent and "it did not find the court's reasoning in Wald persuasive." ${ }^{198}$ Additionally, the Sixth Circuit has held that a distinction between the odor of burnt marijuana and the odor of raw marijuana is insignificant in a probable-cause finding on an automobile. ${ }^{199}$ Combined with the contradictory opinions from the Fifth and Eighth Circuits, at least six federal courts of appeals specifically disagree with the Tenth Circuit's interpretation of Acevedo, promulgated through Nielsen and its progeny.

Certainly, it is within the prerogative of the Tenth Circuit to interpret Supreme Court decisions contrary to other circuits, but the legal framework established by the Tenth Circuit is the lone outlier on the spectrum of possible Ross interpretations. Part of the rationale behind the finality of Supreme Court decisions is to assure that federal law is applied uniformly throughout the numerous jurisdictions of the United States. ${ }^{200}$ Otherwise, an individual's constitutional rights shift depending on their geographic location. As the sole federal jurisdiction to place such a restriction upon law enforcement, the Tenth Circuit has essentially hijacked this particular issue. In fact, after the Tenth Circuit's holding in Nielsen, the FBI Law Enforcement Bulletin published an article on the motor-vehicle exception to the warrant requirement. It stated, "the odor of burnt marijuana alone is generally not viewed by the courts as sufficient to establish probable cause to search the trunk of a vehicle.,201 As support for this generality, the article references the Nielsen decision and cites two state supreme courts that agree with the Tenth Circuit. ${ }^{202}$ While not an official indication of FBI policy, the purpose of the bulletin is to provide the law-enforcement community with guidance, tips, and general principles of law to apply during investigations. By continuing to view Ross through this framework the Tenth Circuit altered the way in which this particular aspect of the Fourth Amendment is regarded and utilized across multiple jurisdictions.

\footnotetext{
198. Id. at 331 .

199. United States v. Foster, 376 F.3d 577, 583-84 (6th Cir. 2004).

200. See, e.g., Margaret Tarkington, Rejecting the Touchstone: Complete Preemption and Congressional Intent After Beneficial National Bank v. Anderson, 59 S.C. L. REV. 225, 252 (2008) ("[A] primary justification for federal jurisdiction is the uniform interpretation of federal law ....").

201. Edward Hendrie, The Motor Vehicle Exception, 74 FBI LAW Enforcement Bull. 22, 25 (2005).

202. Id.; see also, Corr, supra note 1, at 17 ("[O]ne court has held that such an odor [of burnt marijuana] is not enough, when followed by a fruitless search of the passenger compartment, to justify a search of the trunk ....").
} 
The Tenth Circuit expressly permits the odor of burnt marijuana to establish the requisite probable cause for a warrant. Added to a proper reading of Ross, the logical conclusion that follows is that the odor of burnt marijuana provides probable cause to search "every part of the vehicle and its contents that may conceal the object of the search," including the trunk. ${ }^{203}$

\section{B. Resurrection of the Personal-Use Doctrine}

As the previous discussion indicates, the Nielsen decision is based upon the Tenth Circuit's application of Acevedo to the warrantless search of an automobile permitted under Ross. However, with such a fragile legal framework as support for its original holding, the Tenth Circuit eventually expanded the arguments used to justify this rule. Shortly after Nielsen, the Tenth Circuit began to add to the analytical framework for determining probable cause based upon the odor of marijuana. It finally announced its rationale in United States $v$. Wald, pronouncing that "the smell of burnt marijuana is indicative of drug usage, rather than drug trafficking ...."204 In doing so, the Tenth Circuit took a step backward in its Fourth Amendment jurisprudence. Simply stated, the Tenth Circuit improperly resurrected the personal-use doctrine of probable cause.

Federal courts, however, are overwhelmingly unsympathetic to defendants who invoke the theory of personal use in order to obtain suppression. ${ }^{205}$ Drawing a distinction between the odor of burnt and raw marijuana is, from a practical and functional perspective, simply another version of the personal-use doctrine - the smell of raw marijuana suggests drug trafficker and burnt marijuana suggests small quantity user. $^{206}$ Correspondingly, there exists no reason to suspect the automobile contains enough narcotics to rise to the level of distribution. Establishing this bright-line rule as to what circumstances indicate a narcotics trafficker as opposed to a simple user runs contrary to the generally accepted notion that "neither the casual user nor the dealer fits any precise description or category." 207

A bright-line distinction also ignores the possibility of sophisticated narcotics traffickers using burnt marijuana as a masking agent for raw

\footnotetext{
203. United States v. Ross, 456 U.S. 798, 825 (1982).

204. United States v. Wald, 216 F.3d 1222, 1226 (10th Cir. 2000).

205. See United States v. Turner, 119 F.3d 18, 20 (D.C. Cir. 1997) ("Those federal courts that have considered the 'personal use' argument have rejected it . ...").

206. Wald, 216 F.3d at 1226.

207. United States v. Burnett, 791 F.2d 64, 67 (6th Cir. 1986).
} 
marijuana stored in the trunk. This opens the door for traffickers to burn marijuana in the passenger compartment and then discard the corroborating evidence, ${ }^{208}$ knowing that contact with police could only result in a search of the passenger compartment. With a lack of corroborating evidence, law enforcement would be forced to send the suspect on his way. A counter to this contention, however, is that the smell of burnt marijuana provides the officer with enough reasonable suspicion to detain the suspect until a narcotic detecting canine could arrive to verify. ${ }^{209}$ But law enforcement officers need the latitude to do their job without such support, and canine detection is not always a readily available option in the field. Additionally, this distinction imposes upon the officer another complicated layer of decisionmaking. ${ }^{210}$ Not only must he determine whether probable cause exists, but the officer must then run through the analysis of which parts of the automobile are subject to the initial search. Part of the rationale for initially rejecting the personal-use doctrine was to avoid placing such an undue burden upon law enforcement. ${ }^{211}$

The argument for imposing a personal-use doctrine is not only unpersuasive, but is contrary to Tenth Circuit precedent. In Loucks, the Tenth Circuit firmly and unequivocally rejected a distinction between a narcotics amount indicating personal use and one indicating drug trafficking. ${ }^{212}$ Neither Nielsen nor its progeny overruled this wellestablished and widely-accepted principle. Yet this reasoning-once rejected by the Tenth Circuit as "illogical and unreasonable"213 - is now invoked to justify the distinction between burnt and raw marijuana.

Wald unequivocally asserts that the burnt versus raw marijuana distinction is predicated upon a personal-use theory. ${ }^{214}$ The allegedly limiting nature of Acevedo, the key to the Nielsen decision, is now a secondary consideration. Five years after overturning Nielsen's conviction, the Tenth Circuit resurrected a previously discarded theory to support a conclusion based entirely on a credibility determination, rather than a sound analysis of Fourth Amendment precedent.

\footnotetext{
208. See United States v. Reed, 882 F.2d 147, 149 n.4 (5th Cir. 1989) (“"TT]he government noted that Reed could have taken precautions to let the ashes or marihuana residue fall into a cup or other disposable container, which was then discarded before [contact with law enforcement].").

209. United States v. Ramirez, 479 F.3d 1229, 1243 (10th Cir. 2007), abrogated on other grounds by Garrison v. Ortiz, 296 Fed. App'x 724, 726 (10th Cir. 2008).

210. See supra text accompanying notes 201 and 202.

211. Burnett, 791 F.2d at 67.

212. United States v. Loucks, 806 F.2d 208, 210 (10th Cir. 1986).

213. Id. at 210 .

214. United States v. Wald, 216 F.3d 1222, 1226, 1228 (10th Cir. 2000).
} 


\section{Credibility Determination: The Driving Force Behind Nielsen}

The analysis portion of the Nielsen opinion is split into three general themes. First, the Tenth Circuit reviewed the trial court's factual determinations and explained why it disagreed with those findings. ${ }^{215}$ The bulk of the discussion centers around the credibility concerns the Tenth Circuit had about the officer. Second, the opinion reviewed prior Tenth Circuit decisions and explained why Nielsen was distinguishable. ${ }^{216}$ Standing Tenth Circuit precedent at the time, namely Loucks, certainly suggested that the odor of burnt marijuana provided sufficient probable cause to search the trunk of a vehicle. In fact, the Eighth Circuit had previously interpreted Loucks in precisely that manner when it established its own rule. ${ }^{217}$ Third, the Tenth Circuit briefly explained the constitutional precedent that supported its holding. Only two small paragraphs discussed the constitutional justifications. The sheer pervasiveness of the credibility discussion is suggestive, though far from conclusive, that Nielsen was determined on credibility grounds. An extensive look at the language of the opinion is necessary to fully comprehend the extent to which a credibility determination drove the outcome.

\section{The District Court Was Wrong, but Not Clearly Erroneous}

A reading of the Nielsen decision reveals that the Tenth Circuit was concerned with the credibility of Officer Bushnell. Because the trial court made factual findings about credibility, the court of appeals applied the "clearly erroneous" standard of review. ${ }^{218}$ "[A]s is the case with essentially all factual findings based upon credibility," the Tenth Circuit was forced to accept the district court's determination that Officer Bushnell's testimony was credible. ${ }^{219}$

Despite its acceptance of the trial court's findings of fact, the Tenth Circuit explicitly stated that it disagreed with the district court's findings on credibility, but lacked the ability to overturn on that ground. ${ }^{220}$

\footnotetext{
215. United States v. Nielsen, 9 F.3d 1487, 1488-89 (10th Cir. 1993).

216. Id. at $1489-91$.

217. See United States v. Caves, 890 F.2d 87, 90 (8th Cir. 1989) ("Many lower courts have relied primarily upon the odor of marijuana in determining that probable cause existed for a warrantless automobile search." (citing Loucks, 806 F.2d at 209-11)).

218. Nielsen, 9 F.3d at 1489.

219. Id.

220. Id.
} 
Looking at the opinion itself, particularly the language used by the court, the Tenth Circuit's disagreement with this particular outcome is easily ascertained.

In support of the assertion that the Tenth Circuit overturned the conviction based on a credibility determination rather than constitutional precedent, the obvious starting point is the way the Tenth Circuit fashioned the legal question: "The only issue on appeal is whether a police officer's alleged smell of burnt marijuana gave probable cause to search the trunk of the car, when there was no corroborating evidence that defendant had recently smoked marijuana and no marijuana was found in the vehicle." ${ }^{221}$ Framing the question in this manner reveals four aspects of the motion to suppress hearing that undermined the officer's credibility, ultimately allowing one to infer that Officer Bushnell perjured himself on the witness stand by stating he smelled burnt marijuana to validate his otherwise illegal search. First, Nielsen consented to a search of the passenger compartment, but declined a search of the trunk. ${ }^{222}$ The Tenth Circuit pointed out that the search of the trunk was initiated only after the officer learned of Nielsen's prior drug conviction. ${ }^{223}$ The inference to be drawn is that the officer developed suspicion based solely on impermissible factors and developed a rationale after the fact to justify his search. Second, the defendant produced results of a negative urine analysis that demonstrated at the time of the search no marijuana was present in his system. ${ }^{224}$ This result further reduced the probability that marijuana was in the car, making it even more likely that Officer Bushnell fabricated a reason to search. Third, the initial search of the passenger compartment revealed no evidence to corroborate Officer Bushnell's accusation, at which point Officer Bushnell ended his search of the car. ${ }^{225}$ The subsequent search of the trunk took place only after Officer Bushnell discovered the defendant's prior arrest for marijuana possession. ${ }^{226}$ Fourth, the search of the trunk only uncovered cocaine, ${ }^{227}$ an additional indication that Officer Bushnell fabricated his testimony. With each of these operative facts established, the Tenth Circuit explained what possible inferences may be drawn from them.

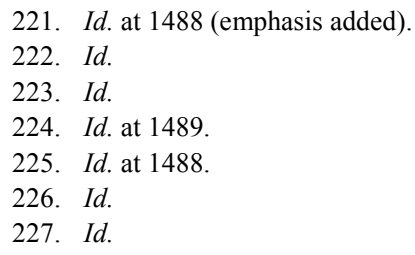


The court struggled to rationalize the "incongruous facts" with the outcome reached by the district court. ${ }^{228}$ Of the three explanations presented, the Tenth Circuit dismissed the one accepted by the district court as the most unlikely-leaving only the credibility determinations. ${ }^{229}$ Either Officer Bushnell mistakenly believed he smelled marijuana or he fabricated the story after the unconstitutional search revealed contraband. ${ }^{230}$ After this discussion as to how the facts failed to support the district court's findings, the Tenth Circuit acknowledged that it was procedurally bound by the lower court's determinations. $^{231}$

Reviewing Nielsen, other courts split on the rationale underlying the Tenth Circuit's decision. A district court in the Third Circuit determined that the holding "appears, in part, to be based on the appellate court's doubts about the credibility of the police in such cases, who the court found have 'an incentive ... to justify [their] actions when [they] search without consent." "232 On the other hand, in United States v. Turner, the D.C. Circuit found that "the court's principal concern was with the credibility of such an uncorroborated observation by an untrained "human sniffer.",233 Either way, the district court in the Third Circuit and the D.C. Circuit both recognized that Nielsen was first and foremost predicated upon a credibility determination by the Tenth Circuit and not upon the announced justification.

\section{Paradigm Shift: No Longer a Probable-Cause Determination}

During a brief discussion and dismissal of Reed - a contradictory decision by the Fifth Circuit - the Tenth Circuit asserted that Reed was the only case that found "probable cause when the smell was not corroborated by the search." 234 Framing its analysis in such a fashion suggests that the Tenth Circuit looked to what the search ultimately revealed as a major factor in making its probable-cause determination. However, the results of a search should not be an indicator of whether probable cause existed before the search commenced. ${ }^{235}$ While no

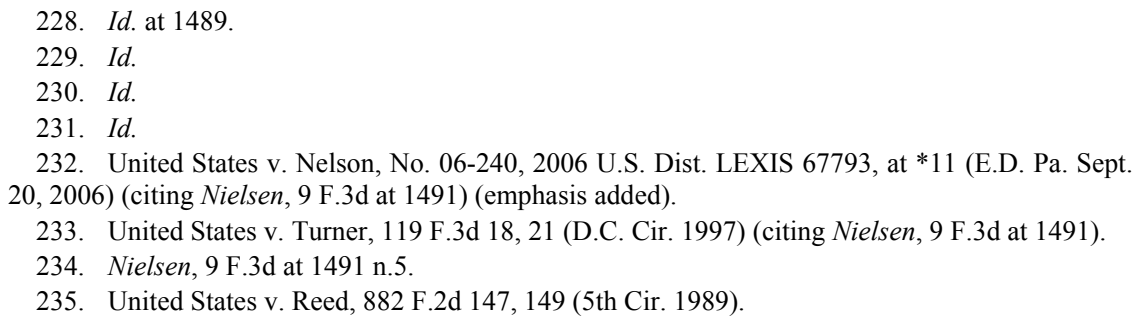


Supreme Court decision is precisely on point, the Court inferred a similar construction of probable cause in stating, "[t]he process does not deal with hard certainties, but with probabilities." ${ }^{236}$ Complete accuracy in uncovering contraband as a result of the search cannot be a requirement for a probable-cause determination. ${ }^{237}$ Requiring every search to produce one-hundred percent accuracy in revealing contraband shifts the standard from a probability to a hard certainty, thereby eliminating a probablecause analysis and replacing it with an outcome-determinative test that decides probable cause only after the search is complete.

The Tenth Circuit essentially imposed its own opinion about the officer's credibility and, in doing so, was forced to alter the probablecause analysis. This alteration replaced the probable-cause analysis with a credibility analysis, an indication that the Nielsen decision was driven by result rather than legal analysis. The Tenth Circuit then developed a legal conclusion from within Fourth Amendment jurisprudence to support its decision.

\section{The Tenth Circuit's Distinction Provides Little Constitutional Protection}

Uncontroverted within the Tenth Circuit is the notion that the odor of burnt marijuana, standing alone, may provide probable cause sufficient to obtain a warrant, ${ }^{238}$ or for a warrantless search of a vehicle under the automobile exception. ${ }^{239}$ The Supreme Court has long recognized that a distinct odor alone may provide a sufficient basis for probable cause. ${ }^{240}$ Several narcotics emit odors distinct enough to adequately allow law enforcement to rely on their own sense of smell in reasonably determining the substance, including marijuana, opium, methamphetamine and $\mathrm{PCP} .{ }^{241}$ Especially after training, an officer is

236. Illinois v. Gates, 462 U.S. 213, 231 (1983) (quoting United States v. Cortez, 449 U.S. 411, $418(1981))$.

237. Michael A. Sprow, Note, Wake Up and Smell the Contraband: Why Courts That Do Not Find Probable Cause Based on Odor Alone Are Wrong, 42 WM. \& MARY L. ReV. 289, 305 (2001).

238. See United States v. Garcia-Zambrano, 530 F.3d 1249, 1260 (10th Cir. 2008) ("We conclude that the frequent observation of the smell of burning marijuana coming from Defendant's apartment, verified on four separate occasions by a trained police officer... was sufficient to support a finding of probable cause.").

239. See Nielsen, 9 F.3d at 1491 (stating that burnt marijuana can only establish probable cause for a search of the passenger compartment).

240. See Johnson v. United States, 333 U.S. 10, 13 (1948) (smell of burning opium establishes probable cause); Taylor v. United States, 286 U.S. 1, 6 (1932) (smell of whiskey is a "fact indicative of possible crime," though it does not allow for a warrantless search).

241. Sprow, supra note 237, at 313. 
unlikely to mistake the odor of marijuana with other substances. ${ }^{242}$ There is little reason not to rely on odor for probable-cause determinations and most courts, particularly federal courts, accept this proposition.

What is in dispute, however, is the permissible scope of a search based solely upon the recognition by a law-enforcement officer of the smell of burnt marijuana emanating from the inside of an automobile. This Comment has argued that the rule promulgated by the Tenth Circuit prohibiting the search of a trunk of an automobile based upon the smell of burnt marijuana is in error. Overturning the rule would bring the Tenth Circuit jurisprudence back in line with other federal circuits and with current Fourth Amendment precedent.

As previously discussed, both justifications asserted by the Tenth Circuit fail to adequately support its black-letter rule. But viewed from a practical standpoint, when applied in the field, the rule becomes little more than a technicality. For example, the Tenth Circuit has upheld the search of a trunk because the officer testified he smelled burnt and raw marijuana. ${ }^{243}$ A search of the passenger compartment revealed no corroborating evidence. ${ }^{244}$ However, when the search of the trunk revealed a large amount of marijuana, the Tenth Circuit automatically determined the officer had probable cause. ${ }^{245}$ Uttering the "magic" words, combined with a positive end result that supported the utterance, meant the court paid little attention to the credibility of the officer. Additionally, Wald denies probable cause to search the trunk only when the search of the passenger compartment fails to reveal any corroborating evidence. $^{246}$ Through subsequent and prior case law, corroborating evidence has developed as little more than a formality. Sufficient corroborating evidence can be as little as a few marijuana seeds ${ }^{247}$ or what one officer believed to be marijuana "residue."248 It appears officers simply need to know the "magic" words that vault them over the incredibly low threshold. With such a low standard for corroboration, the rule may function simply as another hoop for the officer to jump through rather than serving the goal of deterring illegal searches.

242. Richards, supra note 76 , at 360.

243. United States v. Frain, No. 94-4080, 1994 U.S. App. LEXIS 33746, **5-6 (10th Cir. Dec. 1, 1994).

244. Id. at *6. However, the officer's detection of the odor of marijuana was corroborated when he found a "pipe and baggie of marijuana in the defendant's jacket . ..." Id. at *7.

245. Id. at *7.

246. United States v. Wald, 216 F.3d 1222, 1226-28 (10th Cir. 2000).

247. United States v. Loucks, 806 F.2d 208, 211 n.3 (10th Cir. 1986) (citing United States v. Millar, 543 F.2d 1280 (10th Cir. 1976)).

248. United States v. Ashby, 864 F.2d 690, 692 (10th Cir. 1988). 


\section{CONCLUSION}

As the only federal circuit to do so, the Tenth Circuit adopted a "common-sense" distinction between the permissible scope of a search based on the odor of burnt marijuana and a search based on the odor of raw marijuana. The landmark decision spends considerable time analyzing the law-enforcement officer's testimony rather than discussing the constitutional principles leading to its conclusion of law, indicating, as other federal courts have suggested, that the Nielsen decision was based upon a credibility determination. A legal justification based upon Fourth Amendment precedent developed several years after the Tenth Circuit erected the distinction. But the justification ignored clear constitutional principles and resurrected a soundly rejected policy that proved illogical and unreasonable in its application. Nielsen's conclusion was not the product of a thorough constitutional analysis but, instead, a response to a potential perjury by a law-enforcement officer attempting to validate his unconstitutional search. Eventually, this outcome-driven holding developed into a bright-line rule supported by an evolving constitutional framework. The Tenth Circuit's rule is both impractical and contrary to established constitutional precedent. As such, the Tenth Circuit should discard Nielsen and its progeny and replace it with the more accepted interpretation of Ross. Because probable cause for a vehicle encompasses the entire vehicle once an officer detects the odor of burnt marijuana from inside the vehicle, the permissible scope of the search should encompass the entire vehicle, including the trunk. 